\title{
RANCANG BANGUN APLIKASI SISTEM INFORMASI INVENTARISASI SURAT MASUK DAN SURAT KELUAR BERBASIS WEB
}

\author{
Khozin Yuliana ${ }^{1}$ \\ Ahmad Fathi Shofwan ${ }^{2}$ \\ Koko Satria Nuryadin ${ }^{3}$ \\ Dosen STMIK Raharja ${ }^{\text {I }}$ \\ STMIK Raharja Jurusan Sistem Informasi ${ }^{2}$ \\ Alumni STMIK Raharja ${ }^{3}$ \\ Jl. Jendral Sudirman No. 40, Modern Cikokol-Tangerang \\ e-mail:khozin@raharja.info,Ahmad.fathi@raharja.info, kokosatrianuryadin@yahoo.com
}

\begin{abstract}
ABSTRAK
Setiap instansi pasti ada surat masuk dan surat keluarnya yang merupakan sebuah hal yang dapat dijadikan sebagai bukti kegiatan pengeluaran atau pemasukan administrasi selama satu periode. Sistem inventarisasi surat masuk dan surat keluar adalah sistem tentang laporan yang dimiliki oleh setiap instansi yang biasanya terdiri dari bentuk usaha dari suatu instansi. Setiap instansi memiliki sistem surat masuk dan surat keluar yang berbeda-beda, tergantung dengan sistem manajemen yang diterapkan oleh instansi tersebut. Sistem surat masuk dan surat keluar biasanya dilakukan dengan sistem manual. Dengan sistem yang terkomputerisasi akan dapat menjamin adanya waktu yang tetap untuk menghasilkan informasi serta dapat mengontrol mekanisme secara otomatis dengan penerapan kontrol yang baik dan tidak membutuhkan tempat yang luas untuk pengarsipan data karena sebagian besar data disimpan dalam database. Maka penulis melakukan analisis yang hasilnya digambarkan dalam Unified Modeling Language (UML) dengan menggunakan software visual paradigm 6.4. Proses pembuatan sistem dengan menggunakan software PHP dan database MySQL. Hasil penelitian ini diharapkan dapat bermanfaat bagi pengguna terutama pada Direktorat Pencegahan Dan Penyelesaian Perselisihan Hubungan Industrial Ditjen Pembinaan Hubungan Industrial dan Jaminan Sosial Tenaga Kerja.
\end{abstract}

Kata Kunci : Sistem Informasi, Surat Masuk, Surat Keluar, Ditjen, Software, Unified Modeling Language (UML)

\begin{abstract}
There are incoming and outgoing mail can be used as evidence of expenditure or revenue administration activities for one period. Inventory system of incoming mail and outgoing mail is a system ofreporting which is owned by any government agency consisting of the permanent establishment of an agency. Any agency has a different system of incoming and outgoing mail, depending on the management system adopted by that agency. System of incoming and outgoing mail is usually done by manual system. With the computerized system, it will be able to guarantee a fixed time to produce the information and can automatically control mechanism by application of good control and does not require a large place for the archiving of data because most of the data stored in the database. The authors analyzed of the results described in the Unified Modeling Language $(U M L)$ using software visual paradigm 6.4. The process of making software systems using PHP and MySQL database. The results of this research is expected to be useful for users, especially in the
\end{abstract}


Direktorat Pencegahan Dan Penyelesaian Perselisihan Hubungan Industrial Ditjen Pembinaan Hubungan Industrial dan Jaminan Sosial Tenaga Kerja.

KeyWords : Information Systems, incoming mail, outgoing mail, software, Unified Modeling Language (UML)

\section{PENDAHULUAN}

Teknologi Komputerisasi sudah menjadi hal yang umum yang diinginkan oleh semua masyarakat saat ini. Perkembangan ilmu pengetahuan dan teknologi komunikasi semakin maju terutama di bidang komputerisasi. Hal ini merupakan suatu keuntungan bagi semua usaha dan segala aspek bidang lain, karena dengan teknologi komputer dapat mendukung kecepatan dan keakuratan data yang pada akhirnya dapat memberikan informasi secara mudah. Pemenuhan terhadap kebutuhan atas suatu informasi saat ini tidak bisa lepas dari pemanfaatan komputer, khususnya Sistem Informasi. Dibandingkan dengan proses manual, dengan adanya sistem informasi berbasis komputer ini maka pekerjaan yang dihasilkan menjadi lebih efektif dan efisien.

Beberapa alasan kenapa komputer saat ini sangat dibutuhkan dalam pemenuhan kebutuhan informasi yaitu adanya keinginan pengguna untuk mendapatkan informasi secara cepat dan akurat, mampu menangani sistem informasi yang memiliki database yang sangat besar dan alasan-alasan lainnya. Perancangan Sistem Informasi tentang Inventarisasi Surat Masuk dan Surat Keluar sangat bermanfaat untuk Kementerian Tenaga Kerja dan Transmigrasi khususnya pada Direktorat Pencegahan Dan Penyelesaian Perselisihan Hubungan Industrial Ditjen Pembinaan Hubungan Industrial dan Jaminan Sosial Tenaga Kerja maupun pada bagian lainnya untuk memperoleh surat masuk dan surat keluar. Dengan fungsinya tersebut Kementerian Tenaga Kerja dan Transmigrasi pada Direktorat Pencegahan Dan Penyelesaian Perselisihan Hubungan Industrial Ditjen Pembinaan Hubungan Industrial dan Jaminan Sosial Tenaga Kerja perlu membuat suatu sistem tentang surat masuk dan surat keluar yang bermanfaat bagi pegawainya.

Berdasarkan hasil analisa pada sistem yang berjalan tentang sistem informasi inventarisasi surat masuk dan surat keluar pada Direktorat Pencegahan Dan Penyelesaian Perselisihan Hubungan Industrial Ditjen Pembinaan Hubungan Industrial dan Jaminan Sosial Tenaga Kerja, maka permasalahan yang dihadapi adalah selama ini pegawai di Kementerian Tenaga Kerja dan Transmigrasi kesulitan dalam memproses surat masuk dan surat keluar, baik dari surat dari dalam maupun dari luar instansi. Selain itu pada Direktorat Pencegahan Dan Penyelesaian Perselisihan Hubungan Industrial Ditjen Pembinaan Hubungan Industrial dan Jaminan Sosial Tenaga Kerja belum membuat sistem tentang surat masuk dan surat keluar dikarenakan belum ada cara yang efektif untuk membuat sistem tersebut.

\section{TINJAUAN PUSTAKA}

Menurut Kristanto (2008:17), "Surat adalah suatu alat komunikasi yang bersifat tertulis dimana didalamnya mempunyai nilai informasi yang sangat penting, baik dalam keadaan tunggal maupun berkas yang di buat maupun di kirim oleh suatu instansi/organisasi atau perorangan". Surat terbagi menjadi dua macam, yaitu surat masuk dan surat keluar.

a. Surat Masuk

Surat masuk adalah surat yang di terima oleh organisasi/instansi lain atau dari perorangan.

b. Surat Keluar 
Surat keluar adalah surat yang dikirimkan sebagai jawaban/tanggapan atas isi surat masuk yang di terima dari organisasi/ instansi dalam pemerintahan,kantor lain/perorangan agar terjalin rangkaian hubungan timbal balik yang menguntungkan kedua belah pihak.

\section{HASIL DAN PEMBAHASAN}

Dari permasalahan diatas maka dibuatlah sistem yang baru, yang dapat memberikan alternatif perbaikan sistem yang lama dengan sistem yang baru, langkah berikutnya adalah perancangan atau desain sistem baru yang bertujuan untuk perbaikan atau penggantian sistem lama serta memberikan gambaran yang jelas pada admin tentang proses inventarisasi surat masuk dan surat keluar.

Analisa sistem yang dibutuhkan untuk merancang sistem inventarisasi surat masuk dan surat keluar yaitu suatu rancangan use case diagram, activity diagram, sequence diagram, dan state diagram, rancangan basis data serta rancangan tampilan.

\section{Diagram Rancangan Sistem}

Untuk membuat rancangan sistem, maka digunakan program Unified Modeling Language (UML) untuk menggambarkan prosedur dan proses yang saat ini, sebagai berikut :

- Use Case Diagram

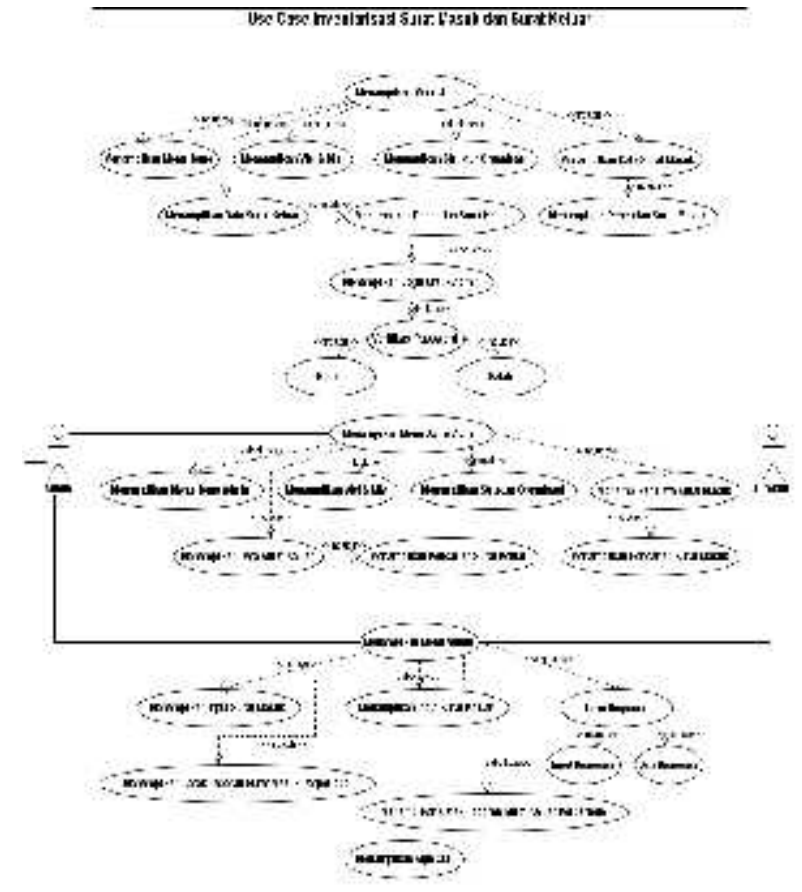

\section{Gambar 1 Use Case Diagram Inventarisasi Surat Masuk dan Surat Keluar}

Berdasarkan gambar 1 Use Case Diagram yang diusulkan terdapat :

a. 1 System yang mencakup seluruh kegiatan admin dalam memproses surat masuk dan surat keluar.

b. 2 Actor yang melakukan kegiatan adalah admin dan Direktur.

c. 4 Use Case yang dilakukan oleh actor.

d. 25 Include yang menspesifikasikan bahwa use case sumber secara eksplisit. 
- Class Diagram

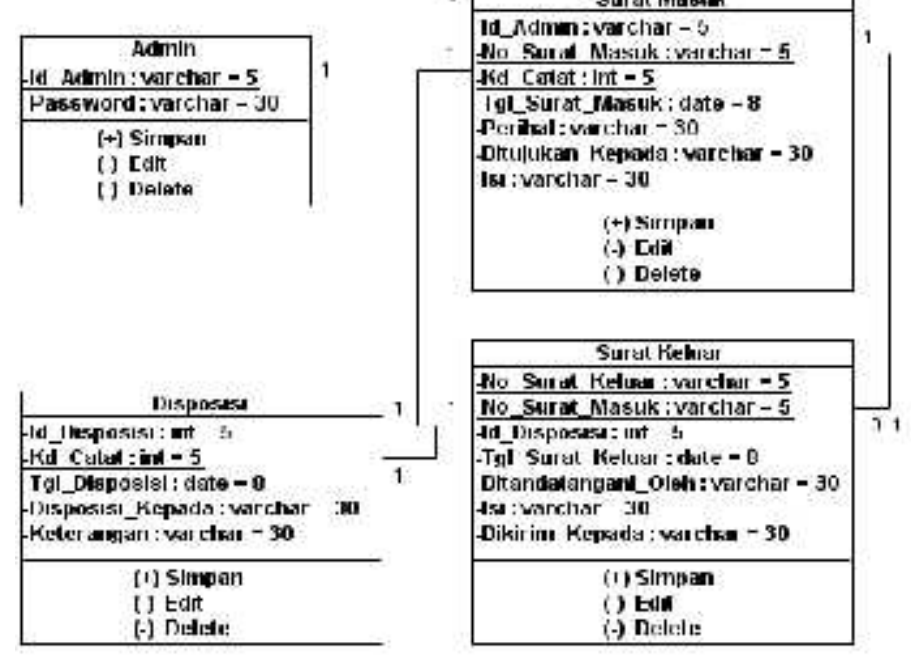

Gambar 2 Class Diagram yang diusulkan

Berdasarkan gambar 2 Class Diagram yang diusulkan terdapat :

a. 4 class, himpunan dari objek-objek yang berbagi atribut serta operasi yang sama diantaranya admin, disposisi, surat masuk, surat keluar.

4 multiplicity, hubungan antara objek satu dengan objek lainnya yang mempunyai nilai.n.

\section{Rancangan Tampilan Yang Diusulkan}

- Desain Menu Utama

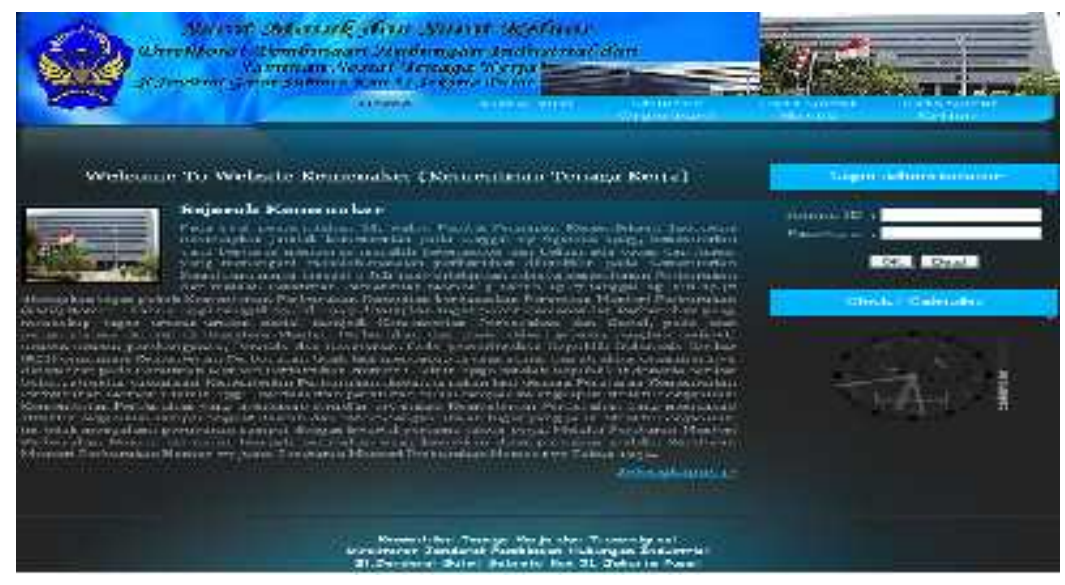

Gambar 3 Desain Menu Utama 
- Desain Visi \& Misi

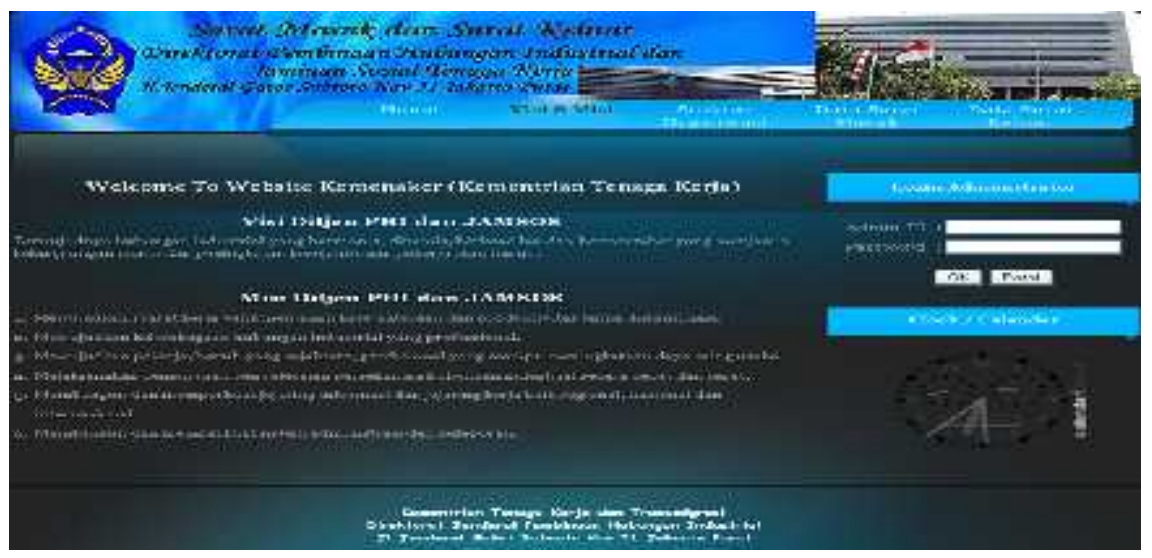

\section{Gambar 4 Desain Visi \& Misi}

- Desain Struktur Organisasi

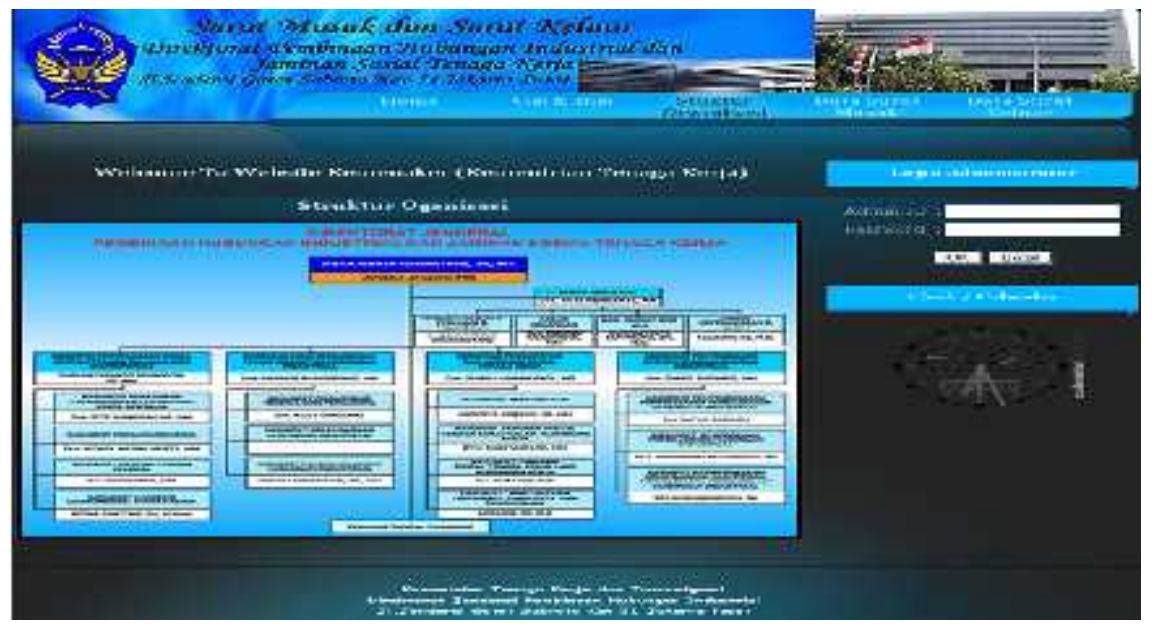

Gambar 5 Desain Struktur Organisasi

- Desain Data Surat Masuk

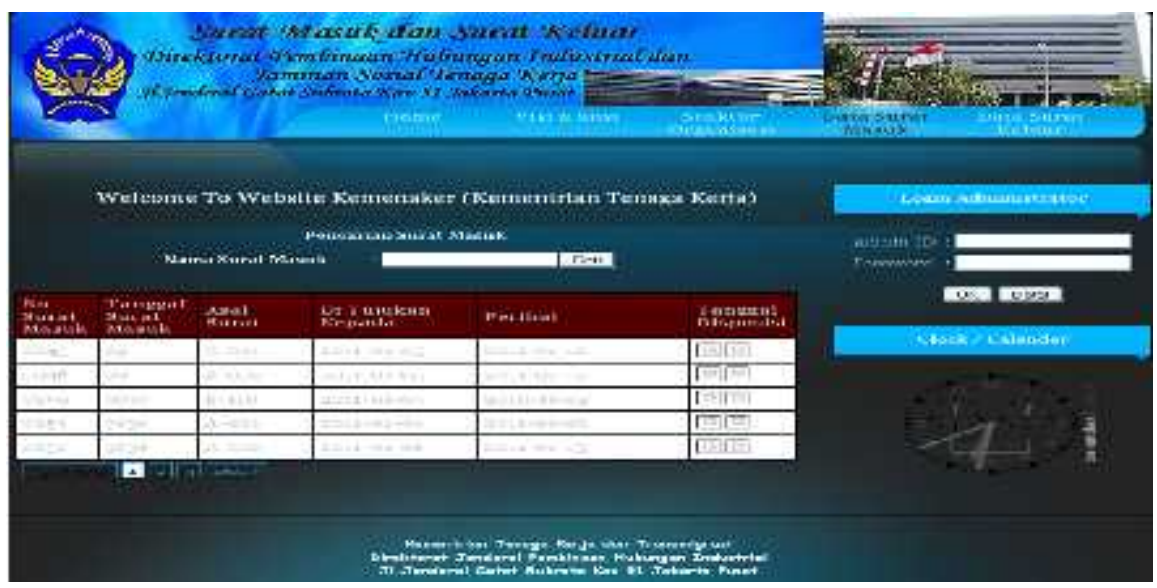

Gambar 6 Desain Data Surat Masuk 
- Desain Data Surat Keluar

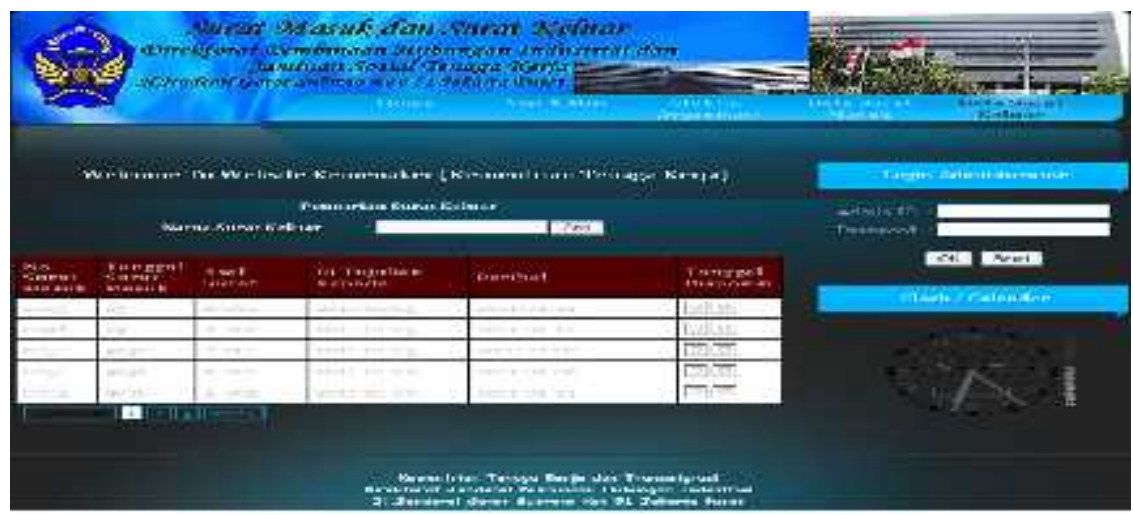

Gambar 7 Desain Data Surat Keluar

- Desain Home Admin

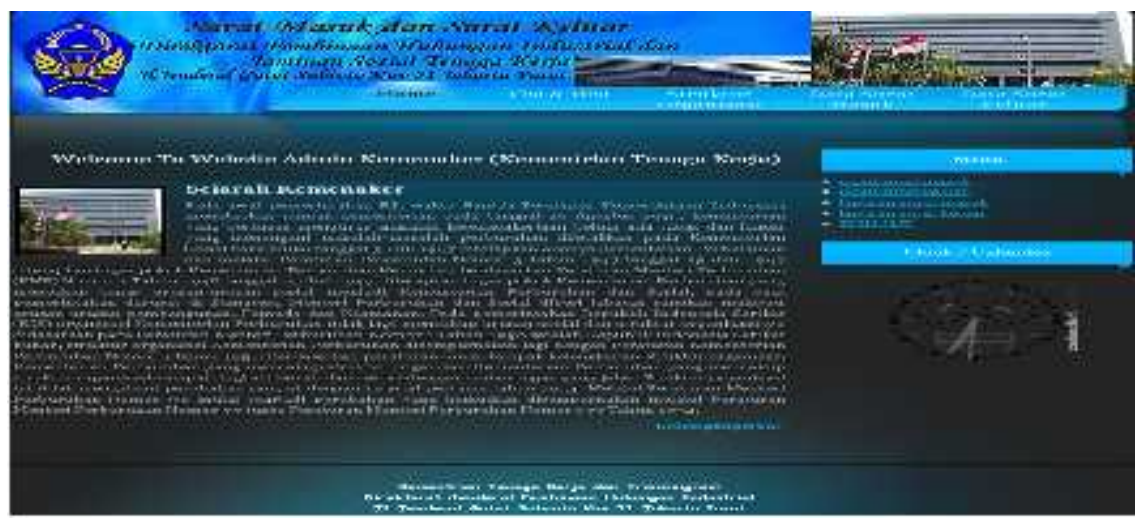

\section{Gambar 8 Desain Home Admin}

- Desain Input Surat Masuk

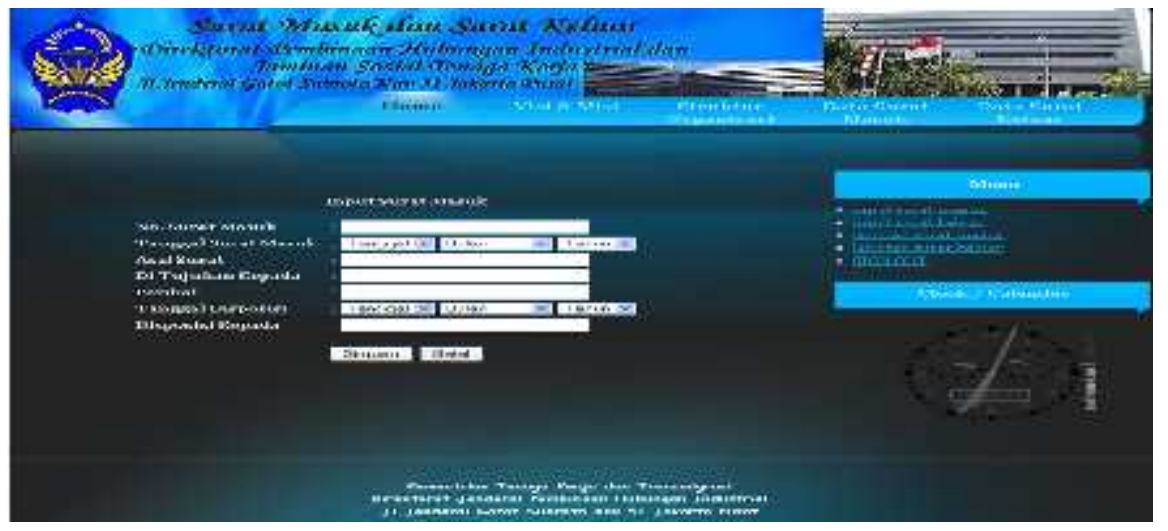

Gambar 9 Desain Input Surat Masuk 
- Desain Input Surat Keluar

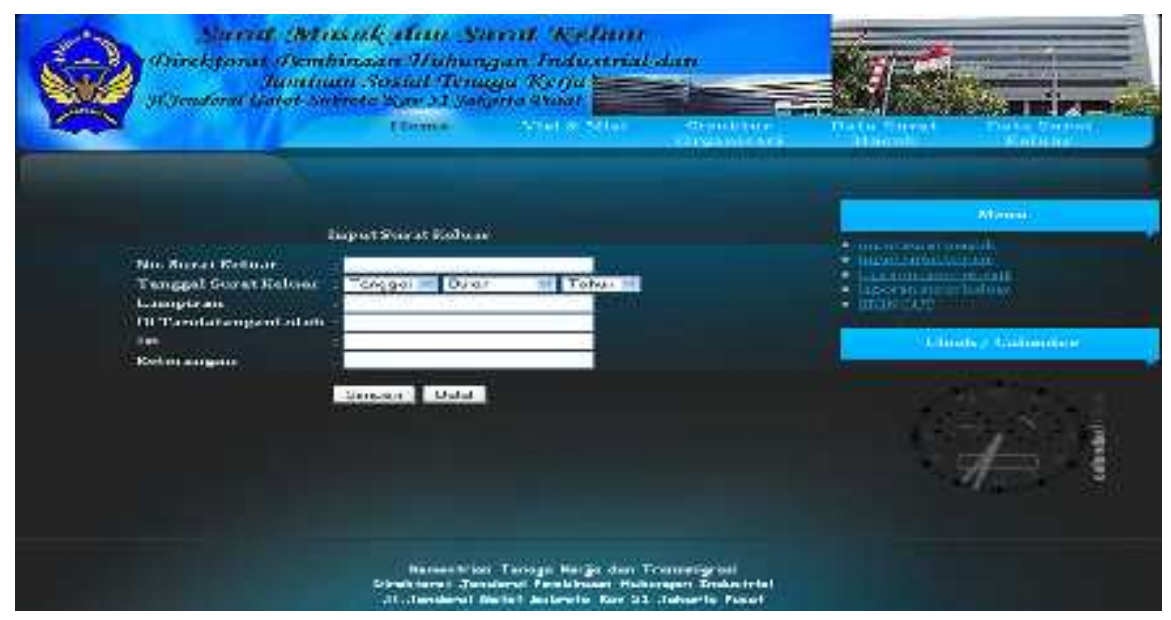

Gambar 10 Desain Input Surat Keluar

- Desain Laporan Surat Masuk

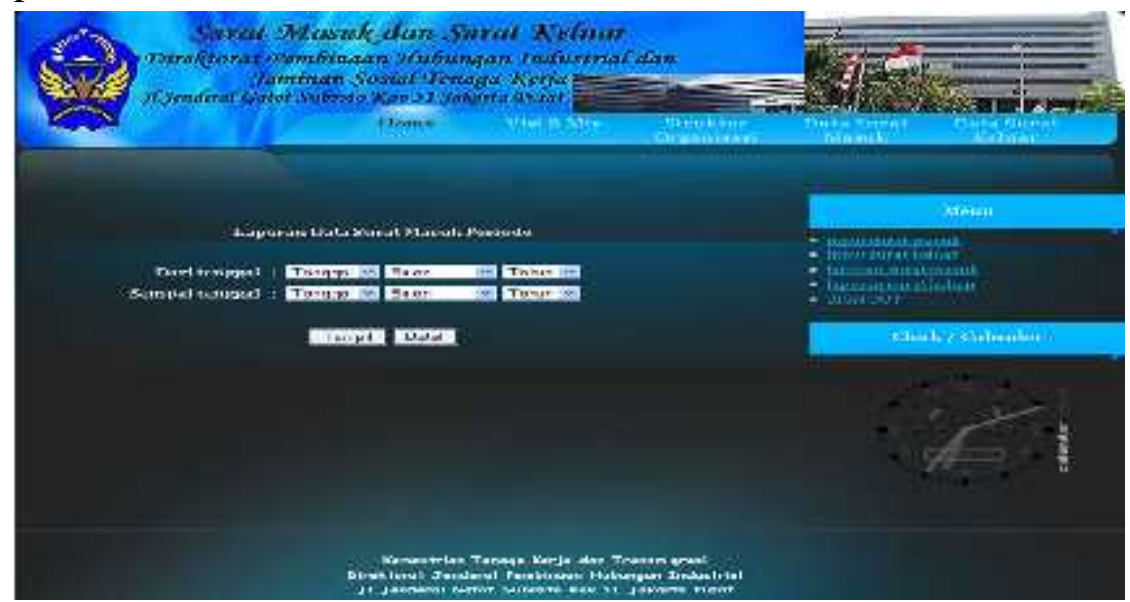

Gambar 11 Desain Laporan Surat Masuk

- Desain Laporan Surat Keluar

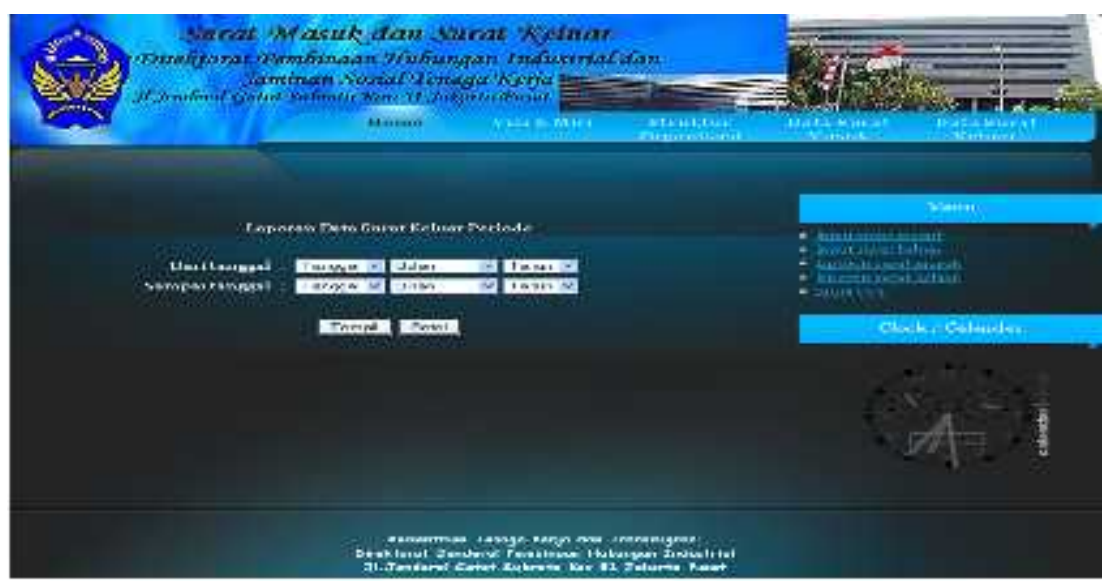

Gambar 12 Desain Laporan Surat Keluar 
Dalam merancang, mempersiapkan, menguji dan mengimplementasikan sistem membutuhkan satuan waktu dalam periode tertentu sehingga dapat berjalan dengan benar, berikut adalah tahapan dalam pengembangan sistem tersebut yaitu :

a. Tahap Pengumpulan Data

Kegiatan pengumpulan data merupakan tahap pertama yang dilakukan, hal ini berguna untuk memenuhi semua kebutuhan data yang diperlukan dalam analisis sistem maupun merancang sistem.

b. Analisa Sistem

Tahapan analisa sistem dilakukan dengan meneliti sistem yang sedang berjalan, tahap ini bertujuan untuk mengetahui segala permasalahan yang terjadi untuk mempermudahkan menentukan tahap selanjutnya yaitu tahap perancangan sistem.

c. Perancangan Sistem

Perancangan sistem dilakukan berdasarkan data yang diperoleh serta analisa pada sistem yang berjalan.

d. Pembuatan Program

Tahap pertama adalah pembuatan program yaitu pembuatan database pada MySQL berdasarkan data yang didapat, lalu merancang bentuk tampilan dilayar kemudian membuat listing program sebagai instruksi dalam menghubungkan tampilan layar tersebut.

e. Testing Program

Bertujuan untuk mengetahui hasil dari program yang telah dibuat pada tahap implementasi sebelumnya.

f. Evaluasi Program

Kegiatan ini dilakukan setelah test program, tujuannya untuk mengetahui kesalahan serta kekurangan pada program yang telah dibuat.

g. Perbaikan Program

Tahap ini dilakukan jika di temukan kekurangan dan kelemahan pada program yang telah dibuat.

h. Pelatihan

Setelah diketahui sudah tidak ada lagi kesalahan dan kekurangan, tahap selanjutnya dilakukan pelatihan terhadap pegawai, maka perancangan sistem yang diusulkan dapat segera diimplementasikan.

i. Dokumentasi

Pengarsipan file yang tersusun rapih sangat membantu memudahkan pencarian data jika terdapat kesalahan nantinya.

\section{KESIMPULAN}

Sistem inventarisasi surat masuk dan surat keluar pada Direktorat Pencegahan Dan Penyelesaian Perselisihan Hubungan Industrial Ditjen Pembinaan Hubungan Industrial dan Jaminan Sosial Tenaga Kerja belum berjalan efektif dikarenakan sistem yang berjalannya masih menggunakan sistem yang manual, sehingga besar peluang untuk kehilangan data dan informasi menjadi tidak akurat. Selain itu proses pengolahan surat masuk dan surat keluar memakan waktu yang lama, sehingga tidak efisien. Dengan rancangan sistem berbasis web menggunakan bahasa pemrograman PHP dan database MySQL sebagai media pengolahan data, admin dapat dengan mudah mengolah data (menginput, mengubah dan menghapus data) tanpa harus memakan waktu yang sangat lama, sampai menyajikannya menjadi informasi yang dibutuhkan user dengan akurat, efektif dan efisien. 


\section{DAFTAR PUSTAKA}

[1] Agus Mulyanto. 2009. Sistem Informasi Konsep dan Aplikasi. Penerbit Pustaka Pelajar. Yogyakarta.

[2] Hartono Jogianto. 2007. “Analisa dan Desain Sistem Informasi Pendekatan Terstruktur Teori dan Praktek Aplikasi Bisnis". Cet.2. Yogyakarta : Andi Offset.

[3] Henderi, S.Kom. 2007. Unified Modelling Language, hal 4. Raharja Enrichment Centre (REC). Tangerang.

[4] Kadir Abdul. 2008. "Latihan Membuat Aplikasi Web PHP dan MySQL dengan Dreamweaver MX (6,7,2004, dan 8)". Edisi Pertama. Yogyakarta : Gava Media.

[5] Kristanto Andi. 2008. "Perancangan Sistem Informasi dan Aplikasinya". Edisi Revisi. Cet.1. Yogyakarta : Gava Media.

[5] Melliana. 2007. "A plikasi Perancangan Sistem Penjualkan Pada CV Yabes Computer B erbasis Web". Tangerang : AMIK Raharja Informatika.

[6] Michael R. Wijela. 2009. “Kursus Kilat 24 jurus". Cet.6. Dinastindo.

[7] Mulyaningsih Ani. 2009. "Perancangan Sistem Komputerisasi Pembelian B arang Pada Swalayan Tip Top Tangerang". Tangerang : AMIK Raharja Informatika.

[8] Nugroho Adi. 2008. "Analisis dan Perancangan Sistem Informasi dengan Metodologi Berorientasi Objek”. Edisi Revisi. Bandung : Informatika.

[9] Nugroho Bunafit. 2008. "Panduan Lengkap Menguasai Perintah SQL". Cet.1. Jakarta : Mediakita.

[10] Oneto Erima dan Sugiarto Yosep. 2009. “Anti Gaptek Internet”. Jakarta : Kawan Pustaka.

[11] Sukarno Mohamad. 2009. "Membangun Website Dinamis Interaktif Dengan PHP-MySQL". Jakarta : Eska Media Press.

[12] Sutabri Tata. 2009. "Sistem Informasi Manajemen". Yogyakarta : Andi.

[13] Ujianto Erik Iman H dan Mambrasar Yusuf. 2008. "Membuat Aplikasi Web Server dengan Winsock". Yogyakarta: Andi. 